\title{
On the age-related loss of smell function
}

\author{
Thomas Hummel \\ From 1st International Workshop on Odor Spaces \\ Hannover, Germany. 4-7 September 2013
}

As already shown more than 100 years ago aging is accompanied by a decrease in intranasal chemosensory sensitivity. Numerous studies confirmed this finding for various odorants and different olfactory tasks, e.g., odor identification, odor detection, odor discrimination, or odor memory. In addition, aging is accompanied by a greater tendency for olfactory adaptation and slower recovery of threshold sensitivity. These age-related changes are detected by means of psychophysical, electrophysiological, and imaging techniques. The anatomical correlate is found both at the level of the olfactory epithelium and at higher centers involved in the processing of olfactory information. Although considerably less data are available regarding age-related changes of intranasal trigeminal chemoreception, its function also appears to decrease in an age-related manner similar to what is seen in the olfactory system. Thus, aging of chemosensory perception seems to be a multi-factorial process. However, age-related changes of the olfactory system do not appear to be an inevitable fate. Studies are needed to explain in what could be done to prevent or delay the age-related change.

Submit your next manuscript to BioMed Central and take full advantage of:

- Convenient online submission

- Thorough peer review

- No space constraints or color figure charges

- Immediate publication on acceptance

- Inclusion in PubMed, CAS, Scopus and Google Scholar

- Research which is freely available for redistribution

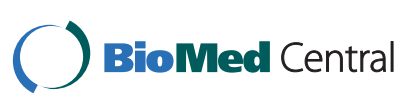

(c) 2014 Hummel; licensee BioMed Central Ltd. This is an Open Access article distributed under the terms of the Creative Commons Attribution License (http://creativecommons.org/licenses/by/2.0), which permits unrestricted use, distribution, and reproduction in any medium, provided the original work is properly cited. The Creative Commons Public Domain Dedication waiver (http:// creativecommons.org/publicdomain/zero/1.0/) applies to the data made available in this article, unless otherwise stated. 